\title{
REFLECTIONS
}

\section{"I Need to Keep Me and My Mother Safe": The Asylum Crisis at the US-Mexico Border}

\author{
Elena Hill, MD, MPH
}

Boston Medical Center, Boston, Massachusetts
Conflicts of interest: author reports none.

\section{CORRESPONDING AUTHOR}

Elena Hill

Boston Medical Center

1 Boston Medical Center Place

Boston, MA 02118

ehill3047@gmail.com

\begin{abstract}
In Tijuana, Mexico, 16-year-old Joaquin, a refugee from El Salvador where LGBTQ people are persecuted, was hoping for asylum in the United States based on sexual orientation. But as a volunteer physician in Tijuana, I had learned hard lessons about the asylum process-or lack thereof-at the US-Mexico border. In 2020, there was a list of over 15,000 asylum seekers at the border in Tijuana seeking a chance at a new life in the United States, but few requests were granted. The lack of transparency about the realities of this system left thousands of families stranded in Mexico without basic rights such as health care. Health care professionals should be aware of the ongoing asylum crisis and be an active faction in the fight for its reform.
\end{abstract}

Ann Fam Med 2021;19:463-465. https://doi.org/10.1370/afm.2698.

\section{INTRODUCTION}

Toaquin was a 16-year-old boy who visited our clinic for refugees in Tijuana, Mexico. He and his mother arrived from El Salvador to seek asylum in the United States. He told me he was gay. He had never told a doctor-he had never told anyone besides his mother-before. He came to be tested for HIV because he had heard that "gay boys get that." He had never been sexually active. He didn't know you have to have sex to get HIV. How could he? Back in El Salvador, where LGBTQ citizens face discrimination, arrest, and beatings, he could never have asked.

During our visit, he acknowledged years of verbal and physical abuse from classmates who suspected his sexuality. His uncle had been molesting him since childhood and threatened to reveal his sexuality if he spoke up. He inquired at the end of our visit: "Doctora, do I look gay to you? Can you tell? I need to make sure no one here knows. I need to keep me and my mother safe."

The acceptance rate for individuals seeking asylum in Tijuana was less than $0.1 \%$, and even lower for those claiming credible fear due to sexual orientation. ${ }^{1}$ I wanted to take Joaquin into my arms and console him. I wanted to congratulate his mother on her bravery and sacrifice taking him across multiple countries to protect his life. But I kept my mouth shut, not wanting to take their hope away. I knew full well that he would never be granted entry to the United States.

\section{THE LIST}

I was a volunteer physician in Tijuana, Mexico in 2019 and 2020. Like most major port-of-entry cities into the United States, Tijuana had a list. A list 15,000 names long of individuals awaiting asylum at the US border. ${ }^{2,3}$ To asylum-seekers, the list meant a chance for life. Or so they believed.

Under international law, individuals have the right to seek asylum in any country of their choosing and that country cannot refuse them if they 
are facing a "credible fear" (as defined in US asylum law) of persecution or torture. ${ }^{1}$ The United States has used multiple systems for circumventing this process, including "the list."

In 1971, Mexico established "Grupos Beta"—a customs and border patrol group-as the asylum authority in Tijuana. Instead of permitting migrants to cross the border to claim asylum as they are entitled under international law, ${ }^{2,4}$ the Betas managed the US "metering system." Migrants added their names to a list and then waited in Mexico for an undefined time. Their name might or might not be called. This list, which put daily limits on the number of asylum seekers called, was illegal under international law. ${ }^{2,4,5}$ Many human rights organizations including the American Civil Liberties Union (ACLU) and Human Rights First have denounced the metering system as unregulated and illegal. ${ }^{2,6}$

As the number of asylum seekers grew unmanageable, the Betas recruited "list managers" who maintained an ever-lengthening list of names. ${ }^{2}$ List managers were themselves often asylum seekers who thought playing their part would help them and their families move up the list. ${ }^{7}$ I fear this was a hollow hope.

Once a person was on the list, they arrived each morning to the border to see if their number was called, granting them the opportunity to formally request asylum. This byzantine process often took months to years. (February 2020 reports from Grupos Beta put the average wait time at 5-6 months. $\left.{ }^{3}\right) \mathrm{On}$ the day one's number was called-if ever-they were escorted to customs facilities, frequently detained without adequate food or clothing, to await the actual moment to submit their preliminary request.

Once asylum was requested, the majority of families were sent back to Mexico under the "Migrant Protection Protocols" (MPP) to await their asylum interview. While cases were ostensibly considered, actual rates of acceptance were less than $0.1 \%{ }^{1}$

With financial support and encouragement from the United States, the Mexican government administered the MPP program. Without real incentive to care for these people, however, the program provided no health insurance or access to care for its participants. I listened to countless stories of people arriving at public hospitals in Mexico with conditions requiring urgent treatment only to be were turned away. If admitted, they were often given substandard treatment. Mexico once offered "Seguro Popular" —a health insurance program for uninsured Mexicans-for a limited number of immigrants. This program qualified patients for coverage for only a few months and took months or even years to obtain. Now, even since my visit in 2019, that program has been disbanded. ${ }^{1}$
The $99.9 \%$ of people who never made it off the list ended up stuck in Mexico-often lacking the resources to return to their home countries and unable to be true citizens of Mexico. Human rights organizations have reported thousands of incidences of murder, torture, rape, and kidnapping of individuals awaiting asylum ${ }^{4}$ under MPP.

The Refugee Health Alliance, the not-for-profit organization I volunteer with, recognized the lack of health care for this extremely vulnerable population as an abomination and, in 2018, founded a clinic to provide them care.

\section{ASYLUM STORIES}

I came to Tijuana in August 2019 as a volunteer physician at Refugee Health Alliance. I returned in August 2020. On both occasions, I witnessed the health care crises families face. With their permission, I share 2 of their incredible stories:

\section{Miguel}

After a violent gang related stabbing, Miguel fled his country for a chance at asylum. He had a chronic colostomy bag at the stabbing site. The surgeon that created the colostomy refused to return to the operating room to close it because Miguel couldn't pay for surgery. He walked around with a hole in his belly. He had no money for supplies to clean the bag, which put him at risk for infection, dehydration, and death.

Miguel would never enter the United States. He waited on the list.

\section{Maria}

Maria came to clinic for her 3-year-old son, who was coughing from the terrible air quality in the refugee shelters. She asked for itch cream for the scabies they contracted from the tent where they slept. She sheepishly asked for a morning-after pill to prevent pregnancy after being raped at the facilities. She fled her country because of repeated rape by her spouse. Here, she faced the same fears, just by a different set of perpetrators. Several years ago, the United States removed rape and sexual assault as eligible criterion for "credible fear."

Maria and her baby would never enter the United States. They waited on the list.

\section{"THE ASYLUM SYSTEM": A CRUEL HOAX}

Whatever a person's views on immigration, encouraging families to uproot their lives, often irreversibly, to end up stranded without legal rights and exposed to physical, emotional, and sexual danger, is unacceptable. 
We are told in the United States that our asylum program offers families a chance to begin anew in America, but I learned in Tijuana that this is a fallacy. Refugees like Joaquin, Miguel, and Maria attempted to respect the law by entering the United States through a legal system at great personal sacrifice. That system was a cruel hoax and the list meant nothing at all.

To read or post commentaries in response to this article, go to https://www.AnnFamMed.org/content/19/5/463/tab-e-letters.

Key words: immigration, health disparities

Submitted August 25, 2020; submitted, revised, January 3, 2021; accepted January 18, 2021.

\section{References}

1. Cuneo $\mathrm{CN}$, Janeway $\mathrm{H}$. From icebox to tinderbox $-\mathrm{a}$ view from the southern border. N Eng J Med. 2020;383(13):381. 10.1056/NEJM p2009985

2. American Immigration Council. Policies affecting asylum seekers at the border. Published Jan 29, 2020. https://www.americanimmigration council.org/research/policies-affecting-asylum-seekers-border

3. University of Texas at Austin Strauss Center for International Security and Law, Center for US-Mexican Studies UC San Diego School of Global Policy \& Strategy. Metering update. Published Feb 2020. https://www.strausscenter.org/wp-content/uploads/MeteringUpdate February_2020.pdf
4. Solis G. Remain in Mexico has a $0.1 \%$ asylum grant rate. Los Angeles Times. December 15, 2019. https://www.latimes.com/world-nation/ story/2019-12-15/remain-in-mexico-has-a-0-01-percent-asylumgrant-rate

5. Fry W, Hennessy-Fiske M. San Diego Union-Tribune. October 1, 2019. Mexican asylum seekers grow frustrated, fearful waiting in border towns from Tijuana to Ciudad Juárez. https://www.sandiegounion tribune.com/news/border-baja-california/story/2019-10-01/backlogof-mexican-asylum-seekers-swells-amid-new-trump-administrationborder-policies

6. Human Rights First. Barred at the border: wait "lists" leave asylum seekers in peril at Texas ports of entry. Published Apr 2019. https:// www.humanrightsfirst.org/sites/default/files/BARRED_AT_THE_ BORDER.pdf

7. Semple K. What is 'La Lista,' which controls migrants' fates in Tijuana? New York Times. November 30, 2018. https://www.nytimes. com/2018/11/30/world/americas/caravan-migrants-tijuana-mexico. html

8. US Citizenship and Immigration Services. Questions and answers: credible fear screening. Updated Jul 15, 2015. https://www.uscis. gov/humanitarian/refugees-and-asylum/asylum/questions-andanswers-credible-fear-screening

\section{STFM CONFERENCE ON MEDIBAL STIIDENT EDUBATION \\ Medical Students and Family Medicine Care Teams Coming Together to Create a Stronger Future for Family Medicine}

\section{EXPLORE}

Conference Topics Include:

- Health Equity, Social Determinants of Health, Well Being, Overcoming Challenges,

- Underrepresented in Medicine Initiatives, Advocacy, Foundational Medical Education Skills, Technological Innovation,

- Creating Change, Precepting, Faculty Development, Coordinator Best Practices,

- Innovative Teaching Techniques, Impacting Climate Change, Medical Marijuana, Addiction, LGBTQ+, PEP/PrEP, and Telehealth

\section{EMPOWER}

- Students, Faculty, and Other Family Medicine Professionals

\section{ADVANCE}

- Family Medicine Medical Student Education

\section{Mark Your Calendars \\ Conference Registration Opens \\ October 25, 2021}

Questions? Contact STFM at (800) 274-7928

\section{or stfm.org/mse}

This conference is for anyone involved in the education of medical students: faculty, students, residents, coordinators, and community preceptors! Share this opportunity with friends, colleagues, and medical students. 